\title{
Kajian Hydrocooling dan Tempat Penyimpanan untuk Mempertahankan Kualitas Cabai Gendot (Capsicum annum var. Abbreviata)
}

\author{
DOI 10.18196/pt.2015.035.16-23
}

\author{
Sukuriyati Suliso Dewi \\ Program Studi Agroteknologi, Fakultas Pertanian, Universitas Muhammadiyah Yogyakarta, \\ Jl. Lingkar Selatan, Kasihan, Bantul, Yogyakarta 55183, \\ e-mail:dewironny_9999@yahoo.com
}

\begin{abstract}
ABSTRAK
Penelitian bertujuan untuk mengetahui pengaruh hydrocooling dalam mempertahankan kualitas cabai gendot dan untuk mengatahui pengaruh tempat peyimpanan pada kualitas cabai gendot. Penelitian dilaksanakan di Laboratorium Pasca Panen dan Kimia Fakultas Pertanian Universitas Muhammadiyah Yogyakarta bulan Juni - Agustus 2007. Penelitian menggunakan metode percobaan laboratorium yang disusun dalam Rancangan Acak Lengkap (RAL) faktorial 2 × 3. Faktor pertama adalah perlakuan hydrocooling yang terdiri dari dari 2 aras yaitu tanpa hydrocooling dan dengan hyrocooling. Faktor kedua adalah tempat penyimpanan yang terdiri dari 3 aras yaitu ice box, cooler dan kulkas. Pengamatan dilakukan selama 20 hari penyimpanan. Parameter pengamatan meliputi susut berat, persentase kerusakan, kekerasan buah, kadar air, vitamin C, kadar gula reduksi, uji mikrobiologi dan uji organoleptic. Hasil penelitian ini menunjukan perlakuan hydrocooling tidak berpengaruh terhadap kualitas buah cabai gendot, kecuali pada perlakuan kadar air, vitamin C, kadar gula reduksi. Tempat penyimpanan tidak berpengaruh terhadap kualitas cabai gendot. Ada Interaksi antara perlakuan hydrocooling dan tempat penyimpanan pada parameter kadar air, kadar vitamin C, kadar gula reduksi.

Kata kunci: Hydrocooling, Tempat penyimpanan, Umur simpan, Cabai gendot
\end{abstract}

\begin{abstract}
The purpose of this study was to understand the effect of hydrocooling and storage on the quality and shelf life of gendot Chili. This study was conducted in Post Harvest Laboratory and Chemistry, Faculty of Agriculture, Universitas Muhammadiyah Yogyakarta. Research was arranged in a completely randomized design (CRD). The first factor is Hydrocooling treatment which consists with and without hydrocooling. The second factor is storage which consist three kind of storage, there are ice box, cooler, and refrigerator. Chili was kept in the storage for 20 days. Parameters of observation were weight losses, damage percentage, fruit hardness, moisture content, vitamin C, reducing sugar, microbiological and organoleptic test. Result showed that hydrocooling treatment was not signicantly effect to the quality of chili. However, hydrocooling treatment is affecting to moisture, Vitamin C, and reducing sugar contents. Storage rooms was not significantly effecting to the quality of chili. There is any interactions between hydrocooling treatment and storage on moisture content, Vitamin C contents, and reducing sugar content.

Keywords: Hydrocooling, Storage, Shelf life, Gendot Chili
\end{abstract}

\section{PENDAHULUAN}

Cabai gendot (Capsinum annum var. Abbreviata) merupakan salah satu komoditas sayuran yang dimanfaatkan untuk keperluan bahan pangan. Ciri dari jenis sayuran ini rasanya pedas dan aromanya khas, buahnya bulat bejol-benjol dan tidak menarik dan tumbuh di daerah dataran Dieng sehingga disebut cabe dieng atau gendot. Cabai gendot merupakan salah satu komoditas pertanian yang mempunyai nilai penting ditengah masyarakat. Cabai dapat dimanfaatkan untuk berbagai keperluan masakan, bahan ramuan obat tadisional maupun industri pengolahan makanan. Secara umum cabai mempunyai banyak kandungan gizi antara lain: vitamin $\mathrm{A}$, vitamin C, kalori, protein, lemak, karbohdrat, kalsium, besi dan fosfor (Setiadi, 2006).

Cabai setelah dilakukan pemanenan sangat rentan terhadap berbagai kerusakan yang terjadi selama penanganan pasca panen yang dapat mencapai 40\% atau lebih. Sifat cabai yang mudah rusak meyebabkan penurunan kualitas dan selang waktu antara saat panen dan komsumsi. 
Salah satu kerusakan yang terjadi adalah kerusakan fisiologis yang dapat menyebabkan penurunan kualitas seperti: tangkai buah menghitam, buah menjadi keriput dan melunak, busuk, pematangan dan perubahan warna. Beberapa cara bisa dilakukan untuk menghindari kerusakan selama penyimpanan yaitu dengan mengunakan tempat penyimpanan seperti kulkas, ice box dan cooler. Penelitian ini bertujuan untuk: (1) Mengetahui pengaruh Hydrocooling untuk mempertahankan kualitas buah cabai. (2) Mengetahui pengaruh tempat penyimpana yang terbaik dalam mempertahankan kualitas buah cabai.

\section{BAHAN DAN METODE}

Penelitian ini dilaksanakan di Laboratorium Pasca Panen dan kimia Fakultas Pertanian Universitas Muhammadiyah Yogyakarta dan Fakultas Teknologi Pertanian Universitas Wangsa Manggala pada bulan Juni 2007 - Agustus 2007.

Bahan yang digunakan dalam penelitian meliputi: cabai dieng, es batu, plastik polietilen 0,4 mm ukuran $1 / 2 \mathrm{~kg}$, kertas saring, aquades, asam asetat gliacial $1 \%$, aseton, ekstrak daging, pepton, agar, $\mathrm{NaOH} 1 \mathrm{~N}$, pb asetat, $\mathrm{Na}-\mathrm{O}$ ksalat dan regensia Nelson. Alat yang digunakan dalam penelitian meliputi: Display cooler, Ice box, kulkas, Autoklaf, oven, botol timbang, labu takar, gelas piala, Petridis, botol timbang, lanu ukur, pipet ukur, spektrofotometer, Optical Deansity (OD) dan coloni counter, thermometer, penetrometer fruit tester, timbangan elektrik.

Percobaan dilakukan di laboratorium dengan Rancangan Acak lengkap (RAL) faktorial 2x3. Faktor pertama adalah pendinginan yang terdiri dari 2 aras yaitu: A1 : Hidrocooling, A2 : Non Hidrocooling. Faktor kedua adalah tempat penyimpanan yang terdiri dari 3 aras yaitu: $\mathrm{B} 1$ : kulkas $\left(10^{\circ}-18^{\circ} \mathrm{C}\right), \mathrm{B} 2$ : cooler $\left(4^{\circ} \mathrm{C}\right), \mathrm{B} 3$ : ice box $\left(0^{\circ}\right.$ $-18^{\circ} \mathrm{C}$ ). Dengan demikian diperoleh 6 kombinasi perlakuan. Kombinasi perlakuan: A1B1: Hidrocooling disimpan dalam kulkas $10-18^{\circ} \mathrm{C}, \mathrm{A} 1 \mathrm{~B} 2$ : Hidrocooling disimpan dalam cooler $4^{\circ} \mathrm{C}, \mathrm{A} 1 \mathrm{~B} 3$ : Hidrocooling disimpan dalam ice box $0-18^{\circ} \mathrm{C}, \mathrm{A} 2 \mathrm{~B} 1$ : Non hidrocooling disimpan dalam kulkas 10$18^{\circ} \mathrm{C}, \mathrm{A} 2 \mathrm{~B} 2$ : Non hidrocooling disimpan dalam cooler $4^{\circ} \mathrm{C}, \mathrm{A} 2 \mathrm{~B} 3$ : Non hidrocooling disimpan dalam ice box $0-18^{\circ} \mathrm{C}$. Masing- masing kombinasi perlakuan diulang 3 kali sehingga terdapat 18 unit perlakuan. Setiap ulangan terdiri dari 4 kemasan. Setiap kemasan berisi 3 buah cabai sehingga diperlakukan 216 buah cabai. Data pengamatan dianalisis dengan sidik ragam pada jenjang (tingkat kesalahan) 5\%. Apabila ada beda nyata antar perlakuan, digunakan Uji Jarak Ganda Duncan atau Duncan's Multiple Range Test (DMRT) dengan tingkat kesalahan 5\%.

\section{HASIL DAN PEMBAHASAN}

\section{Susut Berat}

Hasil sidik ragam susut berat, menunjukkan bahwa tidak ada pengaruh interaksi antara perlakuan hydrocooling dan tempat penyimpanan, Perlakuan hydrocooling menunjukan tidak ada beda nyata dan tempat penyimpanan juga menunjukkan tidak ada beda nyata. Rerata persentase kerusakan penyimpanan hari ke 5, 10, 15 dan 20 di tampilkan dalam Tabel 1 dan 2.

Tabel 1. Pengaruh Hydrocooling terhadap Susut Berat (\%)

\begin{tabular}{lcccc}
\hline \multirow{2}{*}{ Perlakuan } & 5 & 10 & 15 & 20 \\
\cline { 2 - 5 } & $0,50 \mathrm{a}$ & $0,60 \mathrm{a}$ & $0,91 \mathrm{a}$ & $0,85 \mathrm{a}$ \\
\hline Tanpa Hydrocooling & $0,76 \mathrm{a}$ & $0,56 \mathrm{a}$ & $0,56 \mathrm{a}$ & $1,63 \mathrm{a}$ \\
Hydrocooling & \multicolumn{5}{c}{ Susut Berat Hari ke- } \\
\hline Keterangan: Angka yang diikuti huruf yang sama menunjukkan tidak ada beda nyata pada \\
taraf 5\%.
\end{tabular}


Tabel 2. Pengaruh Tempat Penyimpanan terhadap Susut Berat (\%)

\begin{tabular}{lcccc}
\hline \multirow{2}{*}{ Perlakuan } & \multicolumn{4}{c}{ Susut Berat Hari ke- } \\
\cline { 2 - 5 } & 5 & 10 & 15 & 20 \\
\hline Ice box $\left(0-18^{\circ} \mathrm{C}\right)$ & $0,49 \mathrm{a}$ & $0,55 \mathrm{a}$ & $1,09 \mathrm{a}$ & $0,43 \mathrm{a}$ \\
Cooler $\left(4^{\circ} \mathrm{C}\right)$ & $0,80 \mathrm{a}$ & $0,53 \mathrm{a}$ & $0,29 \mathrm{a}$ & $1,24 \mathrm{a}$ \\
Kulkas $\left(10-18^{\circ} \mathrm{C}\right)$ & $0,60 \mathrm{a}$ & $0,67 \mathrm{a}$ & $0,83 \mathrm{a}$ & $2,06 \mathrm{a}$ \\
\hline
\end{tabular}

Keterangan: Angka yang diikuti huruf yang sama menunjukkan tidak ada beda nyata pada taraf $5 \%$

Tabel 1 dan 2 menunjukkan bahwa susut berat cabai setelah pengamatan hari ke 5, 10, 15 dan 20 tidak ada interaksi antara perlakuan hydrocooling dan tempat penyimpanan, perlakuan hydrocooling maupun tanpa hydrocooling menunjukan tidak ada beda nyata atau memberikan pengaruh yang sama. Perlakuan hydrocooling yang dilakukan belum mampu memindahkan panas lapang cabai kemedium pendinginan sehingga laju kehilangan air dan respirasi cabai belum terhambat akibatnya cabai masih mengalami susut berat. Hal ini disebabkan pada semua perlakuan dan semua hari pengamatan suhunya relatif stabil sehingga dapat menghambat proses respirasi dan transpirasi buah.

\section{Kerusakan Buah}

Hasil sidik ragam kerusakan buah, menunjukkan bahwa tidak ada pengaruh interaksi antara perlakuan hydrocooling dan tempat penyimpanan, Perlakuan hydrocooling menunjukan tidak ada beda nyata dan tempat penyimpanan juga menunjukkan tidak ada beda nyata. Rerata persentase kerusakan penyimpanan hari ke 5, 10, 15 dan 20 di tampilkan dalam tabel 3 dan 4.

Tabel 3. Pengaruh Hydrocooling terhadap Kerusakan Buah (\%)

\begin{tabular}{lcccc}
\hline \multirow{2}{*}{ Perlakuan } & \multicolumn{4}{c}{ Kerusakan Buah Hari ke- } \\
\cline { 2 - 5 } & 5 & 10 & 15 & 20 \\
\hline Tanpa Hydrocooling & $27,80 \mathrm{a}$ & $37,03 \mathrm{a}$ & $44,44 \mathrm{a}$ & $70,37 \mathrm{a}$ \\
Hydrocooling & $28,88 \mathrm{a}$ & $40,74 \mathrm{a}$ & $40,74 \mathrm{a}$ & $74,08 \mathrm{a}$ \\
\hline
\end{tabular}

Keterangan: Angka yang diikuti huruf yang sama menunjukkan tidak ada beda nyata pada taraf 5\%.
Tabel 4. Pengaruh Tempat Penyimpanan terhadap Kerusakan Buah (\%)

\begin{tabular}{lcccc}
\hline \multirow{2}{*}{ Perlakuan } & \multicolumn{4}{c}{ Kerusakan Buah Hari ke- } \\
\cline { 2 - 5 } & 5 & 10 & 15 & 20 \\
\hline Ice box $\left(0-18^{\circ} \mathrm{C}\right)$ & $27,36 \mathrm{a}$ & $44,44 \mathrm{a}$ & $50,00 \mathrm{a}$ & $77,78 \mathrm{a}$ \\
Cooler $\left(4^{\circ} \mathrm{C}\right)$ & $31,94 \mathrm{a}$ & $38,89 \mathrm{a}$ & $38,89 \mathrm{a}$ & $66,67 \mathrm{a}$ \\
Kulkas $\left(10-18^{\circ} \mathrm{C}\right)$ & $25,74 \mathrm{a}$ & $33,33 \mathrm{a}$ & $38,89 \mathrm{a}$ & $72,23 \mathrm{a}$ \\
\hline
\end{tabular}

Keterangan: Angka yang diikuti huruf yang sama menunjukkan tidak ada beda nyata pada taraf 5\%.

Tabel 3 dan 4 menunjukan bahwa perlakuan hydrocoling dan tanpa hydrocooling serta tempat penyimpanan cabai memberikan pengaruh yang sama dalam menghambat kerusakan cabai selama penyimpanan. Hal ini menunjukkan bahwa perlakuan hydrocooling yang dilakukan belum dapat menghambat laju traspirasi dan respirasi cabai sehingga cabai yang diberi perlakuan hydrocooling masih mengalami kerusakan. Dari tabel 4 diketahui bahwa penyimpanan cabai memberikan pengaruh yang sama terhadap kerusakan cabai, pada penyimpan hari ke 5, 10, 15 dan 20 penyimpanan. Kerusakan buah pada tempat penyimpanan ice box, cooler dan kulkas mulai tampak pada pengamatan hari ke 10. Kerusakan buah tempat penyimpanan kulkas $\left(10-18^{\square} \mathrm{C}\right)$ cenderung lebih tinggi dan bentuk kerusakannya kulit buah berubah dari warna hijau menjadi warna kuning dan bercampur merah kecoklatan hampir 50\%.

\section{Kekerasan Buah}

Hasil sidik ragam kekerasan cabai pada penyimpanan hari ke 5, 10, 15 dan 20, menunjukkan bahwa tidak ada pengaruh interaksi antara perlakuan hydrocooling dan tempat penyimpanan, Perlakuan hydrocooling menunjukan tidak ada beda nyata dan tempat penyimpanan juga menunjukkan tidak ada beda nyata. Rerata kekerasan buah pada penyimpanan hari ke 5,10 , 15 dan 20 ditampilkan dalam tabel 5 dan 6. 
Tabel 5. Pengaruh Hydrocooling terhadap Kekerasan Buah (gram/detik)

\begin{tabular}{lcccc}
\hline \multirow{2}{*}{ Perlakuan } & \multicolumn{4}{c}{ Kekerasan Buah Hari ke- } \\
\cline { 2 - 5 } & 5 & 10 & 15 & 20 \\
\hline Tanpa Hydrocooling & $0,50 \mathrm{a}$ & $0,60 \mathrm{a}$ & $0,91 \mathrm{a}$ & $0,85 \mathrm{a}$ \\
Hydrocooling & $0,76 \mathrm{a}$ & $0,56 \mathrm{a}$ & $0,56 \mathrm{a}$ & $1,63 \mathrm{a}$ \\
\hline
\end{tabular}

Keterangan: Angka yang diikuti huruf yang sama menunjukkan tidak ada beda nyata pada taraf $5 \%$.

Tabel 6. Pengaruh Tempat Penyimpanan terhadap Kekerasan Buah (gram/detik)

\begin{tabular}{lcccc}
\hline \multirow{2}{*}{ Perlakuan } & \multicolumn{4}{c}{ Kekerasan Buah Hari ke- } \\
\cline { 2 - 5 } & 5 & 10 & 15 & 20 \\
\hline Ice box $\left(0-18^{\circ} \mathrm{C}\right)$ & $0,49 \mathrm{a}$ & $0,55 \mathrm{a}$ & $1,09 \mathrm{a}$ & $0,43 \mathrm{a}$ \\
Cooler $\left(4^{\circ} \mathrm{C}\right)$ & $0,80 \mathrm{a}$ & $0,53 \mathrm{a}$ & $0,29 \mathrm{a}$ & $1,24 \mathrm{a}$ \\
Kulkas $\left(10-18{ }^{\circ} \mathrm{C}\right)$ & $0,60 \mathrm{a}$ & $0,67 \mathrm{a}$ & $0,83 \mathrm{a}$ & $2,06 \mathrm{a}$ \\
\hline
\end{tabular}

Keterangan: Angka yang diikuti huruf yang sama menunjukkan tidak ada beda nyata pada taraf $5 \%$.

Dari tabel 5 dan 6 diketahui bahwa perlakuan tanpa hydrocooling dengan perlakuan hydrocooling dan tempat penyimpan menunjukkan pengaruh yang sama dalam mempertahankan kekerasan cabai selama penyimpanan. Hal ini menunjukkan bahwa perlakuan hydrocooling belum dapat mempertahankan kekerasan buah cabai.

\section{Kadar Air}

Hasil sidik ragam kadar air cabai pada penyimpanan hari ke 5, 10, 15 dan 20, menunjukan bahwa pada hari ke 5 penyimpanan terdapat interaksi antar perlakuan hydrocooling dan penyimpanan dan terdapat beda nyata antar perlakuan tanpa hydrocooling dan hydrocooling, sedangkan pada hari ke 10, 15 dan 20 tidak ada pengaruh interaksi antara perlakuan hydrocooling dengan tempat penyimpanan dan tidak ada beda nyata antar perlakuan tanpa hydrocooling dan hydrocooling. Rerata kadar air cabai pada penyimpanan hari ke 5, 10, 15 dan 20 ditampilkan dalam tabel 7, 8 dan 9 .

Pada tabel 7 diketahui bahwa perlakuan hydrocooling dan tanpa hydrocooling, memberikan pengaruh nyata dalam mempertahankan kadar air selama penyimpanan. Hal ini menujukan bahwa perlakuan hydrocooling yang dilakukan dapat menghambat kadar air cabai. Sedangkan tabel 8 diketahui bahwa perlakuan hydrocooling dan tanpa hydrocooling memberikan pengaruh yang sama dalam mempertahankan kadar air cabai selama penyimpanan. Hal ini menunjukan bahwa perlakuan hydrocooling yang dilakukan belum dapat memindahkan panas lapang cabai kemedium hydrocooling sehingga laju respirasi dan traspirasi cabai tetap berlangsung cepat. Dari tabel 9 diketahui bahwa tempat penyimpanan ice box dengan suhu $\left(0-18^{\circ} \mathrm{C}\right)$, cooler $\left(4^{\circ} \mathrm{C}\right)$ dan kulkas $\left(10-18^{\circ} \mathrm{C}\right)$ memberikan pengaruh yang sama dalam mempertahankan kadar air cabai. Hal ini menunjukan bahwa penyimpanan dengan suhu $0-18^{\circ} \mathrm{C}, 4^{\circ} \mathrm{C}$ dan $10-18^{\circ} \mathrm{C}$ belum efektif menghambat laju penurunan.

Tabel 7. Persentase Kadar Air (\%) pada Penyimpanan Hari ke- 5

\begin{tabular}{lcccc}
\hline \multirow{2}{*}{ Perlakuan } & \multicolumn{3}{c}{ Tempat Simpan } & \multirow{2}{*}{ Rerata } \\
\cline { 2 - 4 } & $\begin{array}{c}\text { Ice box } \\
\left(0-18^{\circ} \mathrm{C}\right)\end{array}$ & $\begin{array}{c}\text { Cooler } \\
\left(4{ }^{\circ} \mathrm{C}\right)\end{array}$ & $\begin{array}{c}\text { Kulkas } \\
\left(10-18{ }^{\circ} \mathrm{C}\right)\end{array}$ & \\
\hline Tanpa Hydrocooling & $89,50 \mathrm{~b}$ & $91,70 \mathrm{a}$ & $90,50 \mathrm{ab}$ & 90,57 \\
Hydrocooling & $92,27 \mathrm{a}$ & $90,37 \mathrm{ab}$ & $91,12 \mathrm{ab}$ & 91,25 \\
\hline Rerata & 90,88 & 91,03 & 90,81 & $(+)$ \\
\hline
\end{tabular}

Keterangan : Angka yang diikutin huruf yang sama menunjukkan tidak ada beda nyata berdasarkan uji jarak berganda DMRT pada tarif 5\%. (+): Ada interaksi.

Tabel 8. Kadar Air (\%) pada Penyimpanan Hari ke- 10, 15 dan 20

\begin{tabular}{lcccc}
\hline \multirow{2}{*}{ Perlakuan } & 5 & 10 & 15 & 20 \\
\cline { 2 - 5 } & 5 & $0,60 \mathrm{a}$ & $0,91 \mathrm{a}$ & $0,85 \mathrm{a}$ \\
\hline Tanpa Hydrocooling & $0,50 \mathrm{a}$ & $0,56 \mathrm{a}$ & $0,56 \mathrm{a}$ & $1,63 \mathrm{a}$ \\
\hline
\end{tabular}

Keterangan: Angka yang diikuti huruf yang sama menunjukkan tidak ada beda nyata pada taraf $5 \%$. 
Tabel 9. Persentase Kadar Air (\%) pada Penyimpanan Hari ke- 10, 15 dan 20

\begin{tabular}{lcccc}
\hline \multirow{2}{*}{ Perlakuan } & \multicolumn{5}{c}{ Kadar Air Hari ke- } \\
\cline { 2 - 5 } & 5 & 10 & 15 & 20 \\
\hline Ice box $\left(0-18^{\circ} \mathrm{C}\right)$ & $0,49 \mathrm{a}$ & $0,55 \mathrm{a}$ & $1,09 \mathrm{a}$ & $0,43 \mathrm{a}$ \\
Cooler $\left(4^{\circ} \mathrm{C}\right)$ & $0,80 \mathrm{a}$ & $0,53 \mathrm{a}$ & $0,29 \mathrm{a}$ & $1,24 \mathrm{a}$ \\
Kulkas $\left(10-18^{\circ} \mathrm{C}\right)$ & $0,60 \mathrm{a}$ & $0,67 \mathrm{a}$ & $0,83 \mathrm{a}$ & $2,06 \mathrm{a}$ \\
\hline
\end{tabular}

Keterangan: Angka yang diikuti huruf yang sama menunjukkan tidak ada beda nyata pada taraf 5\%

\section{Kadar Vitamin C}

Hasil sidik ragam vitamin $\mathrm{C}$ cabai pada penyimpanan hari ke 5, 10, 15 dan 20, menunjukan bahwa pada hari ke 5, 10 dan 15 penyimpanan terdapat interaksi antara perlakuan hydrocooling dan penyimpanan terdapat beda nyata antar perlakuan tanpa hydrocooling dan hydrocooling, sedangkan pada hari ke 20 penyimpanan tidak terdapat interaksi antara perlakuan hydrocooling dan penyimpanan terdapat beda nyata antar perlakuan tanpa hydrocooling dan hydrocooling .

Rerata vitamin C pada penyimpanan hari ke 5, 10, 15 dan 20 ditampilkan dalam tabel 10, 11, 12 dan 13.

Tabel 10. Persentase Vitamin C (mg) pada Penyimpanan Hari ke- 5

\begin{tabular}{lcccc}
\hline \multirow{2}{*}{ Perlakuan } & \multicolumn{3}{c}{ Tempat Simpan } & Rerata \\
\cline { 2 - 4 } & $\begin{array}{c}\text { Ice box } \\
\left(0-18^{\circ} \mathrm{C}\right)\end{array}$ & $\begin{array}{c}\text { Cooler } \\
\left(4^{\circ} \mathrm{C}\right)\end{array}$ & $\begin{array}{c}\text { Kulkas } \\
\left(10^{\circ}-18^{\circ} \mathrm{C}\right)\end{array}$ & \\
\hline Tanpa Hydrocooling & $40,20 \mathrm{a}$ & $30,20 \mathrm{~b}$ & $27,98 \mathrm{~b}$ & 32,79 \\
Hydrocooling & $39,09 \mathrm{a}$ & $22,44 \mathrm{c}$ & $22,99 \mathrm{c}$ & 28,17 \\
\hline Rerata & 39,65 & 26,32 & 25,48 & $(+)$ \\
\hline
\end{tabular}

Keterangan : Angka yang diikutin huruf yang sama menunjukkan tidak ada beda nyata berdasarkan uji jarak berganda DMRT pada tarif $5 \%$. (+): Ada interaksi.

Tabel 11. Rerata Persentase Vitamin C (mg) pada Penyimpanan Hari ke- 10

\begin{tabular}{lcccc}
\hline \multirow{2}{*}{ Perlakuan } & \multicolumn{3}{c}{ Tempat Simpan } & \\
\cline { 2 - 4 } & $\begin{array}{c}\text { Ice box } \\
\left(0-18^{\circ} \mathrm{C}\right)\end{array}$ & $\begin{array}{c}\text { Cooler } \\
\left(4{ }^{\circ} \mathrm{C}\right)\end{array}$ & $\begin{array}{c}\text { Kulkas } \\
\left(10-10^{\circ} \mathrm{C}\right)\end{array}$ & Rerata \\
\hline Tanpa Hydrocooling & $21,89 \mathrm{c}$ & $20,22 \mathrm{c}$ & $16,34 \mathrm{~d}$ & 19,48 \\
Hydrocooling & $26,98 \mathrm{~b}$ & $21,89 \mathrm{c}$ & $35,18 \mathrm{a}$ & 28,02 \\
\hline Rerata & 24,44 & 21,06 & 25,76 & $(+)$ \\
\hline
\end{tabular}

Keterangan : Angka yang diikutin huruf yang sama menunjukkan tidak ada beda nyata berdasarkan uji jarak berganda DMRT pada tarif 5\%. (+): Ada interaksi.
Tabel 12. Rerata Persentase Vitamin C (mg) pada Penyimpanan Hari ke- 15

\begin{tabular}{lcccc}
\hline \multirow{2}{*}{ Perlakuan } & \multicolumn{3}{c}{ Tempat Simpan } & \multirow{2}{*}{ Rerata } \\
\cline { 2 - 4 } & $\begin{array}{c}\text { Ice box } \\
\left(0-18^{\circ} \mathrm{C}\right)\end{array}$ & $\begin{array}{c}\text { Cooler } \\
\left(4{ }^{\circ} \mathrm{C}\right)\end{array}$ & $\begin{array}{c}\text { Kulkas } \\
\left(10-10^{\circ} \mathrm{C}\right)\end{array}$ & \\
\hline Tanpa Hydrocooling & $25,21 \mathrm{~b}$ & $18,00 \mathrm{~d}$ & $26,31 \mathrm{~b}$ & 23,17 \\
Hydrocooling & $33,52 \mathrm{a}$ & $22,99 \mathrm{c}$ & $35,18 \mathrm{a}$ & 30,56 \\
\hline Rerata & 29,37 & 20,50 & 30.75 & $(+)$ \\
\hline
\end{tabular}

Keterangan : Angka yang diikutin huruf yang sama menunjukkan tidak ada beda nyata berdasarkan uji jarak berganda DMRT pada tarif 5\%. (+): Ada interaksi.

Tabel 13. Rerata Persentase Vitamin C (mg) pada Penyimpanan Hari ke- 20

\begin{tabular}{lcccc}
\hline \multirow{2}{*}{ Perlakuan } & \multicolumn{3}{c}{ Tempat Simpan } & \multirow{2}{*}{ Rerata } \\
\cline { 2 - 4 } & $\begin{array}{c}\text { Ice box } \\
\left(0-18^{\circ} \mathrm{C}\right)\end{array}$ & $\begin{array}{c}\text { Cooler } \\
\left(4^{\circ} \mathrm{C}\right)\end{array}$ & $\begin{array}{c}\text { Kulkas } \\
\left(10-10^{\circ} \mathrm{C}\right)\end{array}$ \\
\hline Tanpa Hydrocooling & 21,89 & 16,89 & 18,56 & $19,11 \mathrm{a}$ \\
Hydrocooling & 21,33 & 16,89 & 18,56 & $18,93 \mathrm{a}$ \\
\hline Rerata & $21,61 \mathrm{a}$ & $16,89 \mathrm{c}$ & $18,56 \mathrm{~b}$ & $(-)$ \\
\hline
\end{tabular}

Keterangan : Angka yang diikutin huruf yang sama menunjukkan tidak ada beda nyata berdasarkan uji jarak berganda DMRT pada tarif 5\%. (-): Tidak ada interaksi.

Berdasarkan tabel 10, 11 dan 12 di ketahui bahwa perlakuan hydrocooling dan tanpa hydrocooling memberikan pengaruh yang nyata dalam mempertahankan penurunan vitamin $\mathrm{C}$ buah cabai selama penyimpanan. Hal ini menunjukan bahwa perlakuan hydrocooling yang dilakukan dapat menghambat kegiatan respirasi dan transpirasi buah sehingga proses perombakan pati menjadi gula-gula sederhana terhambat akibatnya penurunan kadar vitamin $\mathrm{C}$ tidak terjadi selama penyimpanan sedangkan pada tabel ke 13 perlakuan hydrocooling dan tanpa hydrocooling memberikan pengaruh yang sama dalam mempertahankan penurunan vitamin $\mathrm{C}$ buah cabai selama penyimpanan. Penurunan vitamin $\mathrm{C}$ akibat buah mengalami perombakan pati menjadi gula-gula sederhana.

\section{Kadar Gula Reduksi}

Hasil sidik ragam kadar gula reduksi cabai (lampiran II.21, II. 22, II.23 dan II.24) pada penyimpanan hari ke 5, 10, 15 dan 20 menunju. kan ada beda nyata pada semua perlakuan dan 
dapat diketahui terdapat interaksi antar perlakuan hydrocooling dan tempat penyimpanan. Rerata kadar gula reduksi penyimpanan hari ke 5, 10, 15 dan 20 ditampilkan pada tabel 14, 15, 16 dan 17.

Tabel 14. Rerata Persentase Kadar Gula Reduksi (\%) Pada Penyimpanan Hari ke- 5

\begin{tabular}{lcccc}
\hline \multirow{2}{*}{ Perlakuan } & \multicolumn{3}{c}{ Tempat Simpan } & \\
\cline { 2 - 4 } & $\begin{array}{c}\text { Ice box } \\
\left(0-18^{\circ} \mathrm{C}\right)\end{array}$ & $\begin{array}{c}\text { Cooler } \\
\left(4{ }^{\circ} \mathrm{C}\right)\end{array}$ & $\begin{array}{c}\text { Kulkas } \\
\left(10^{\circ}-18^{\circ} \mathrm{C}\right)\end{array}$ & Rerata \\
\hline Tanpa Hydrocooling & $1,97 \mathrm{~b}$ & $1,62 \mathrm{e}$ & $2,47 \mathrm{a}$ & 2,02 \\
Hydrocooling & $1,86 \mathrm{c}$ & $2,45 \mathrm{a}$ & $1,76 \mathrm{~d}$ & 2,02 \\
\hline Rerata & 1,92 & 2,04 & 2,12 & $(+)$ \\
\hline
\end{tabular}

Keterangan : Angka yang diikutin huruf yang sama menunjukkan tidak ada beda nyata berdasarkan uji jarak berganda DMRT pada tarif 5\%. (+): Ada interaksi.

Tabel 15. Rerata Persentase Kadar Gula Reduksi (\%) pada Penyimpanan Hari ke- 10

\begin{tabular}{lcccc}
\hline \multirow{2}{*}{ Perlakuan } & \multicolumn{3}{c}{ Tempat Simpan } & Rerata \\
\cline { 2 - 4 } & $\begin{array}{c}\text { Ice box } \\
\left(0-18^{\circ} \mathrm{C}\right)\end{array}$ & $\begin{array}{c}\text { Cooler } \\
\left(4^{\circ} \mathrm{C}\right)\end{array}$ & $\begin{array}{c}\text { Kulkas } \\
\left(10-10^{\circ} \mathrm{C}\right)\end{array}$ & \\
\hline Tanpa Hydrocooling & $1,69 \mathrm{bc}$ & $1,89 \mathrm{~b}$ & $1,86 \mathrm{~b}$ & 1,81 \\
Hydrocooling & $1,58 \mathrm{c}$ & $1,79 \mathrm{bc}$ & $2,25 \mathrm{a}$ & 1,87 \\
\hline Rerata & 1,64 & 1,84 & 2,06 & $(+)$ \\
\hline
\end{tabular}

Keterangan : Angka yang diikutin huruf yang sama menunjukkan tidak ada beda nyata berdasarkan uji jarak berganda DMRT pada tarif 5\%. (+): Ada interaksi.

Tabel 16. Rerata Persentase Kadar Gula Reduksi (\%) pada Penyimpanan Hari ke- 15

\begin{tabular}{lcccc}
\hline \multirow{2}{*}{ Perlakuan } & \multicolumn{3}{c}{ Tempat Simpan } & \\
\cline { 2 - 4 } & $\begin{array}{c}\text { Ice box } \\
\left(0-18^{\circ} \mathrm{C}\right)\end{array}$ & $\begin{array}{c}\text { Cooler } \\
\left(4{ }^{\circ} \mathrm{C}\right)\end{array}$ & $\begin{array}{c}\text { Kulkas } \\
\left(10-18^{\circ} \mathrm{C}\right)\end{array}$ & \\
\hline Tanpa Hydrocooling & $1,90 \mathrm{ab}$ & $1,62 \mathrm{~d}$ & $1,96 \mathrm{a}$ & 1,83 \\
Hydrocooling & $1,87 \mathrm{~b}$ & $1,92 \mathrm{ab}$ & $1,70 \mathrm{c}$ & 1,83 \\
\hline Rerata & 1,89 & 1,77 & 1,83 & $(+)$ \\
\hline
\end{tabular}

Keterangan : Angka yang diikutin huruf yang sama menunjukkan tidak ada beda nyata berdasarkan uji jarak berganda DMRT pada tarif 5\%. (+): Ada interaksi.

Tabel 17. Rerata Persentase Kadar Gula Reduksi (\%) pada Penyimpanan Hari ke- 20

\begin{tabular}{lcccc}
\hline \multirow{2}{*}{ Perlakuan } & \multicolumn{3}{c}{ Tempat Simpan } & \\
\cline { 2 - 4 } & $\begin{array}{c}\text { Ice box } \\
\left(0-18^{\circ} \mathrm{C}\right)\end{array}$ & $\begin{array}{c}\text { Cooler } \\
\left(4{ }^{\circ} \mathrm{C}\right)\end{array}$ & $\begin{array}{c}\text { Kulkas } \\
\left(10-10^{\circ} \mathrm{C}\right)\end{array}$ & Rerata \\
\hline Tanpa Hydrocooling & $89,50 \mathrm{~b}$ & $91,70 \mathrm{a}$ & $90,50 \mathrm{ab}$ & 90,57 \\
Hydrocooling & $92,27 \mathrm{a}$ & $90,37 \mathrm{ab}$ & $91,12 \mathrm{ab}$ & 91,25 \\
\hline Rerata & 90,88 & 91,03 & 90,81 & $(+)$ \\
\hline
\end{tabular}

Keterangan : Angka yang diikutin huruf yang sama menunjukkan tidak ada beda nyata berdasarkan uji jarak berganda DMRT pada tarif 5\%. (+): Ada interaksi.
Berdasarkan tabel 14, 15, 16 dan 17 di ketahui bahwa pada hari ke 5, 10, 15 dan 20 penyimpanan, kadar gula reduksi kombinasi perlakuan hydrocooling dan tempat penyimpanan berbeda nyata dengan perlakuan lainya. Kadar gula reduksi tinggi akan mengakibatkan proses perombakan pati menjadi gula-gula sederhana kurang dapat dihambat sehingga proses perombakan-perombakan yang terjadi berlangsung dengan cepat, kenaikan suhu dapat meningkatkan laju respirasi buah. Kadar gula reduksi rendah juga mengakibatkan laju respirasi cabai berlangsung lambat karena suhu ruang penyimpanan yang rendah dan relatif stabil sehingga dapat menghambat proses perombakan pati menjadi gula sederhana.

\section{Uji Mikrobiologi \\ Jamur}

Hasil sidik ragam jumlah jamur pada hari ke 5, 10, 15 dan 20 penyimpanan menunjukkan bahwa tidak ada pengaruh interaksi antara perlakuan hydrocooling dan tempat penyimpanan dan tidak ada beda nyata antara perlakuan hydrocooling maupun tempat penyimpanan terhadap jumlah jamur. Rerata jumlah jamur pada penyimpanan hari 5, 10, 15 dan 20 di tampilkan dalam tabel 18 dan 19.

Tabel 18. Pengaruh Hydrocooling terhadap Jumlah Jamur

\begin{tabular}{lcccc}
\hline \multirow{2}{*}{ Perlakuan } & 5 & 10 & 15 & 20 \\
\cline { 2 - 5 } & $0,50 \mathrm{a}$ & $0,60 \mathrm{a}$ & $0,91 \mathrm{a}$ & $0,85 \mathrm{a}$ \\
\hline Tanpa Hydrocooling & $0,76 \mathrm{a}$ & $0,56 \mathrm{a}$ & $0,56 \mathrm{a}$ & $1,63 \mathrm{a}$ \\
\hline
\end{tabular}

Keterangan: Angka yang diikuti huruf yang sama menunjukkan tidak ada beda nyata pada taraf $5 \%$. 
Tabel 19. Pengaruh Tempat terhadap Jumlah Jamur

\begin{tabular}{lcccc}
\hline \multirow{2}{*}{ Perlakuan } & \multicolumn{4}{c}{ Jumlah Jamur Hari ke- } \\
\cline { 2 - 5 } & 5 & 10 & 15 & 20 \\
\hline Ice box $\left(0-18^{\circ} \mathrm{C}\right)$ & $0,49 \mathrm{a}$ & $0,55 \mathrm{a}$ & $1,09 \mathrm{a}$ & $0,43 \mathrm{a}$ \\
Cooler $\left(4^{\circ} \mathrm{C}\right)$ & $0,80 \mathrm{a}$ & $0,53 \mathrm{a}$ & $0,29 \mathrm{a}$ & $1,24 \mathrm{a}$ \\
Kulkas $\left(10-18^{\circ} \mathrm{C}\right)$ & $0,60 \mathrm{a}$ & $0,67 \mathrm{a}$ & $0,83 \mathrm{a}$ & $2,06 \mathrm{a}$ \\
\hline
\end{tabular}

Keterangan: Angka yang diikuti huruf yang sama menunjukkan tidak ada beda nyata pada taraf $5 \%$.

Dari tabel 18 dan 19 terlihat bahwa perlakuan hydrocooling memberikan pengaruh yang sama dalam menghambat pertumbuhan jamur. Hal ini menunjukan bahwa perlakuan hydrocooling yang dilakukan belum dapat menghambat pertumbuhan mikrobia terutama jamur. Berdasakan tabel 19 di ketahui bahwa pada tempat penyimpanan ice box $\left(0-18^{\circ} \mathrm{C}\right)$, cooler $\left(4^{\circ} \mathrm{C}\right)$ dan Kulkas $\left(10-18^{\circ} \mathrm{C}\right)$ memberikan pengaruh yang sama dalam menghambat pertumbuhan jamur. Hal ini menunjukkan bahwa semua perlakuan tempat simpan belum dapat menghambat pertumbuhan jamur.

\section{Bakteri}

Hasil sidik ragam jumlah bakteri menunjukkan bahwa tidak ada pengaruh interaksi antara perlakuan hydrocooling dan tempat simpan, dan tidak ada beda nyata antar perlakuan. Hal ini menunjukan bahwa perlakuan hydrocooling dan tempat simpan memberikan pengaruh yang sama dalam menghambat pertumbuhan bakteri selama penyimpanan.

Tabel 20. Pengaruh Hydrocooling terhadap Jumlah Bakteri

\begin{tabular}{lcccc}
\hline \multirow{2}{*}{ Perlakuan } & 5 & 10 & 15 & 20 \\
\cline { 2 - 5 } & $0,50 \mathrm{a}$ & $0,60 \mathrm{a}$ & $0,91 \mathrm{a}$ & $0,85 \mathrm{a}$ \\
\hline Tanpa Hydrocooling & $0,76 \mathrm{a}$ & $0,56 \mathrm{a}$ & $0,56 \mathrm{a}$ & $1,63 \mathrm{a}$ \\
Hydrocooling & & & \\
\hline Keterangan: Angka yang diikuti huruf yang sama menunjukkan tidak ada beda nyata pada \\
taraf 5\%.
\end{tabular}

Tabel 21. Pengaruh Hydrocooling terhadap Jumlah Bakteri

\begin{tabular}{lcccc}
\hline \multirow{2}{*}{ Perlakuan } & \multicolumn{4}{c}{ Jumlah Bakteri Hari ke- } \\
\cline { 2 - 5 } & 5 & 10 & 15 & 20 \\
\hline Ice box $\left(0-18^{\circ} \mathrm{C}\right)$ & $0,49 \mathrm{a}$ & $0,55 \mathrm{a}$ & $1,09 \mathrm{a}$ & $0,43 \mathrm{a}$ \\
Cooler $\left(4^{\circ} \mathrm{C}\right)$ & $0,80 \mathrm{a}$ & $0,53 \mathrm{a}$ & $0,29 \mathrm{a}$ & $1,24 \mathrm{a}$ \\
Kulkas $\left(10-18{ }^{\circ} \mathrm{C}\right)$ & $0,60 \mathrm{a}$ & $0,67 \mathrm{a}$ & $0,83 \mathrm{a}$ & $2,06 \mathrm{a}$ \\
\hline
\end{tabular}

Keterangan: Angka yang diikuti huruf yang sama menunjukkan tidak ada beda nyata pada taraf $5 \%$.

Berdasarkan tabel 20 diketahui bahwa pada hari ke 5, 10, 15 dan 20 penyimpanan jumlah bakteri perlakuan tanpa hydrocooling dan hydrocooling memberikan pengaruh yang sama dalam menghambat pertumbuhan bakteri. Pertumbuhan bakteri mengalami peningkatan selama penyimpanan. Berdasarkan tabel 21 diketahui bahwa pada hari ke 5, 10, 15 dan 20 penyimpanan jumlah bakteri pada tempat penyimpanan ice box dengan tempat simpan $\left(0-18^{\circ} \mathrm{C}\right)$, cooler $\left(4^{\circ} \mathrm{C}\right)$ dan kulkas $\left(10-18^{\circ} \mathrm{C}\right)$ memberikan pengaruh yang sama dalam menghambat pertumbuhan bakteri. Pertumbuhan bakteri perlakuan tempat simpan $4^{\circ} \mathrm{C}$ relatif lebih banyak selama penyimpanan. Hal ini menunjukan bahwa penyimpanan yang dilakukan pada suhu berfluktuatif dan kelembaban tinggi lebih memacu pertumbuhan mikrobia terutama bakteri.

\section{Uji Organoleptik}

Tabel 22. Rerata Uji Organoleptik Warna dan Kesegaran pada Penyimpanan Hari ke 5,10,15, 20

\begin{tabular}{|c|c|c|c|c|c|c|c|c|}
\hline \multirow{2}{*}{ Hari Pengamatan } & \multicolumn{4}{|c|}{ Warna } & \multicolumn{4}{|c|}{ Kesegaran } \\
\hline & 5 & 10 & 15 & 20 & 5 & 10 & 15 & 20 \\
\hline Tanpa hydro, $0-18^{\circ} \mathrm{C}$ & 1.0 & 1.0 & 1.5 & 1.5 & 2.0 & 2.0 & 2.0 & 3.0 \\
\hline Tanpa hydro, $4^{\circ} \mathrm{C}$ & 1.0 & 1.1 & 1.4 & 1.6 & 1.0 & 1.1 & 1.4 & 2.0 \\
\hline Tanpa hydro, $10-18^{\circ} \mathrm{C}$ & 1.0 & 2.3 & 2.6 & 3.0 & 1.0 & 2.3 & 2.6 & 3.0 \\
\hline Hydro, $0-18^{\circ} \mathrm{C}$ & 1.0 & 1.6 & 2.2 & 2.3 & 1.0 & 1.6 & 2.2 & 3.0 \\
\hline Hydro, $4^{\circ} \mathrm{C}$ & 1.0 & 1.0 & 1.4 & 1.7 & 1.0 & 1.0 & 1.4 & 2.6 \\
\hline Hydro, $10-18^{\circ} \mathrm{C}$ & 1.0 & 2.4 & 2.5 & 2.5 & 1.0 & 2.4 & 2.5 & 2.5 \\
\hline $\begin{array}{l}\text { Keterangan: } \\
\qquad \begin{array}{l}\text { Warna Buah: } \\
1=\text { Hijau } \\
2=\text { Hijau kekuningan } \\
3 \text { = Kuning kemerahan }\end{array}\end{array}$ & & & & & $\begin{array}{l}\text { garan } \\
\text { Segar } \\
\text { Agak } \\
\text { Kerip }\end{array}$ & & & \\
\hline
\end{tabular}


Dari tabel 22 terlihat bahwa skor warna terendah (disukai konsumen) diperoleh pada kombinasi perlakuan hydrocooling dengan tempat simpan $4^{\circ} \mathrm{C}$, karena kombinasi perlakuan ini mampu mengendalikan laju respirasi dan transpirasi buah sehingga menghambat degradrasi klorofil dan proses pematangan buah. Kesegaran masingmasing kombinasi perlakuan mengalami perubahan selama penyimpanan kecuali pada perlakuan hydrocooling dan tanpa hydrocooling tempat simpan $4^{\circ} \mathrm{C}$ sampai hari ke 20 buah masih segar. Nilai kualitas penampakan tertinggi diperoleh pada perlakuan hydrocooling pada tempat penyimpanan cooler $\left(4^{\circ} \mathrm{C}\right)$ dengan skor 2,6, karena perlakuan hydrocooling dan tempat penyimpanan cooler $\left(4^{\circ} \mathrm{C}\right)$ lebih mampu mempertahankan kesegaran buah dibandingkan perlakuan lainya.

\section{SIMPULAN}

Perlakuan hydrocooling belum mampu menpertahankan kualitas cabai selama penyimpanan. Tempat penyimpanan dengan tempat simpan dapat mempertahankan kualitas cabai yaitu cooler $\left(4^{\circ} \mathrm{C}\right)$. Interaksi terjadi pada perlakuan hydrocooling dan tempat simpan pada parameter kekerasan buah yaitu pada pengamatan hari ke 20, kadar air yaitu pada pengamatan hari ke 5 dan kadar vitamin $\mathrm{C}$ yaitu pengamatan hari ke 5, 10 dan 20 dan kadar gula reduksi pada semua pengamatan.

\section{DAFTAR PUSTAKA}

Setiadi. 2006. Cabai Rawit Jenis dan Budaya. Jakarta. Penebar Swadaya. 